\title{
KESIAPAN ORGANISASI DALAM IMPLEMENTASI STANDAR ISO 37001 (STUDI KASUS DI UD. X DAN DINAS Y)
}

\section{The Readiness of Organizations In Implementation of Standard ISO 37001 (Case Study in Venture. $X$ and Office $Y$ )}

\author{
Reza Lukiawan \\ Pusat Penelitian dan Pengembangan Standardisasi, Badan Standardisasi Nasional \\ Gedung I BPPT Lantai 12, Jalan M.H. Thamrin No. 8, Jakarta, Indonesia \\ e-mail: lukiawan@bsn.go.id
}

Diterima: 2 Juli 2018, Direvisi: 20 Juli 2018, Disetujui: 1 Agustus 2018

\begin{abstract}
Abstrak
Praktik korupsi di Indonesia menjadi fenomena yang sangat mencemaskan, karena telah meluas dan merambah pada lembaga eksekutif, legislatif, dan yudikatif. Kondisi tersebut menjadi salah satu faktor penghambat pembangunan di Indonesia. Melakukan penyuapan merupakan salah satu bentuk tindak pidana korupsi. ISO telah mempublikasikan ISO 37001:2016 - Anti bribery management systems - Requirements with guidance for use untuk membantu organisasi memerangi suap. Standar ini dapat diterapkan untuk apapun bentuk organisasinya dan telah diadopsi menjadi SNI oleh BSN. Penelitian ini bertujuan untuk menganalisis tingkat kesiapan organisasi dalam implementasi ISO 37001. Penelitian ini merupakan penelitian studi kasus dengan menggunakan metode analisis gap untuk mengetahui tingkat kesiapan implementasi standar yang dilakukan organisasi. Studi kasus dilakukan pada organisasi di UD. X di kota Yogyakarta dan Dinas $Y$ yang berada di kota Palembang. Hasil penelitian menunjukkan bahwa tingkat kesiapan implementasi standar pada organisasi UD. X berada pada level ready dengan nilai rata-rata untuk tujuh aspek kriteria standar sebesar 3,32. Sedangkan hasil tingkat kesiapan implementasi standar pada organisasi Dinas $Y$ masih berada pada level preliminary dengan nilai rata-rata untuk tujuh aspek kriteria standar sebesar 2,55. Manfaat penelitian ini adalah sebagai pilot project penerapan sistem manajemen anti penyuapan sehingga dapat membantu suatu organisasi mencegah terjadinya kasus suap yang melibatkan oknum perorangan atau yang terorganisir dilakukan oleh korporasi.
\end{abstract}

Kata kunci: korupsi, sistem manajemen anti penyuapan, kesiapan organisasi, ISO 37001.

\begin{abstract}
The practice of corruption in Indonesia has become a very worrying phenomenon, as it has become widespread and extended to the executive, legislative, and judicial institutions. This condition has become one of the obstacles to development in Indonesia. Conducting bribery is one form of corruption. ISO has published ISO 37001: 2016 - Anti bribery management systems - Requirements with guidance for use to help organizations fight bribery. This standard can be applied to any form of organization and has been adopted into SNI by BSN. This study aims to analyze the level of organizational readiness in the implementation of ISO 37001 . This study is a case study research using gap analysis methods to determine the level of readiness of implementation standards conducted by the organization. Case studies were conducted at organizations in Venture. $X$ in the city of Yogyakarta and Office $Y$ in the city of Palembang. The results showed that the level of readiness of standard implementation on organization Venture. $X$ is at the ready level with an average score for seven aspects of standard criteria of 3.32. While the results of the standard implementation level of readiness on the organization office $Y$ is still at the preliminary level with the average score for the seven aspects of the standard criteria of 2.55. The benefits of this research is as a pilot project of anti-bribery management system so that it can help an organization prevent the happening of bribery case involving individual person or organized by corporation.
\end{abstract}

Keyword: corruption, anti-bribery management system, organizational readiness, ISO 37001.

\section{PENDAHULUAN}

Korupsi merupakan tindakan oportunis para oknum yang sangat merugikan perekonomian negara dan memberi dampak buruk bagi seluruh elemen masyarakat. Korupsi yang banyak terjadi semakin menyulitkan suatu negara dalam upaya mengentaskan kemiskinan. Praktik korupsi di
Indonesia sudah menjadi fenomena yang sangat mencemaskan, karena telah semakin meluas dan merambah pada lembaga eksekutif, legislatif, dan yudikatif. Kondisi tersebut telah menjadi salah satu faktor penghambat utama pelaksanaan pembangunan di Indonesia. Ketidakberhasilan pemerintah memberantas korupsi juga semakin melemahkan citra 
pemerintah dimata masyarakat dalam pelaksanaan pemerintahan yang tercermin dalam bentuk ketidakpercayaan masyarakat, ketidakpatuhan masyarakat terhadap hukum, dan bertambahnya jumlah angka kemiskinan absolut (Fauzan dkk, 2012).

Tindak korupsi terbagi menjadi beberapa bentuk, salah satunya penyuapan. Dewasa ini tindak pidana suap tidak hanya dilakukan oleh perorangan saja, akan tetapi juga oleh korporasi. Dalam kasus-kasus korupsi besar (grand corruption) yang melibatkan keputusankeputusan pemerintah pada tingkat atas, seringkali korporasi terlibat di dalamnya. Dalam hal ini, pihak korporasi berusaha mendominasi pengambilan keputusan di tingkat pejabat negara tingkat atas dengan jalan memberi uang sogokan atau suap. Dapat dikatakan bahwa kasus-kasus korupsi yang melibatkan korporasi ini hanyalah fenomena gunung es dari budaya suap-menyuap dalam menjalankan bisnis di negeri ini. Pemberian uang suap menjadi semacam cara bagi korporasi dalam mempermudah proyekproyek bisnis mereka (Subinarto, 2017).

Kasus penyuapan yang berhasil diungkap oleh Komisi Pemberantasan Korupsi (KPK) menunjukkan angka yang memprihatinkan. Data yang dilansir dari laman KPK diperoleh data kasus tindak pidana penyuapan berturut-turut pada tahun 2009 sebanyak 12 kasus, tahun 2010 sebanyak 19 kasus, tahun 2011 sebanyak 25 kasus, tahun 2012 sebanyak 34 kasus, tahun 2013 sebanyak 50 kasus, tahun 2014 sebanyak 20 kasus, tahun 2015 sebanyak 38 kasus, dan tahun 2016 sebanyak 69 kasus (Suprapto \& Lukiawan, 2017). Data tersebut mencerminkan adanya peningkatan jumlah kasus penyuapan meski disisi lain sebagai indikator keberhasilan KPK dalam memberantas korupsi di Indonesia.

Pemerintah tengah berupaya keras mencegah terjadinya korupsi agar tidak semakin membebani kerugian negara. Melalui Instruksi Presiden Republik Indonesia Nomor 10 Tahun 2016 tentang Aksi Pencegahan dan Pemberantasan Korupsi, pemerintah saat ini berupaya mengkoordinasikan peran antar lembaga pemerintah sesuai dengan tugas pokok dan fungsinya untuk melaksanakan aksi pencegahan dan pemberantasan korupsi. Upaya ini selaras dengan ISO yang telah mempublikasikan ISO 37001:2016 - Anti bribery management systems - Requirements with guidance for use (Sistem manajemen antipenyuapan - Persyaratan dengan panduan penggunaan) untuk membantu organisasi memerangi suap dan mempromosikan budaya bisnis yang etis. ISO 37001 Anti bribery management systems - Requirements with guidance for use menetapkan serangkaian langkah untuk membantu organisasi mencegah, mendeteksi dan mengatasi penyuapan. ISO 37001 dapat digunakan oleh setiap organisasi, besar atau kecil, baik di sektor publik, swasta atau yayasan. ISO 37001 merupakan alat yang fleksibel, yang dapat disesuaikan dengan ukuran dan sifat organisasi dan risiko suap yang dihadapinya (Suprapto \& Lukiawan, 2017).

Penanganan korupsi selama ini menghadapi berbagai hambatan serius yang dikelompokkan menjadi empat (Djoyosoekarto $\mathrm{dkk}, 2008)$. Pertama, hambatan struktural, yaitu hambatan yang bersumber dari praktek-praktek penyelenggaraan negara dan pemerintahan yang membuat penanganan tindak pidana korupsi tidak berjalan sebagaimana mestinya. Termasuk dalam kelompok ini diantaranya meliputi egoisme sektoral dan institusional yang menjurus pada pengajuan dana sebanyak-banyaknya untuk sektor dan instansinya tanpa memperhatikan kebutuhan nasional secara keseluruhan serta berupaya menutup-nutupi penyimpanganpenyimpangan yang terdapat di sektor dan instansi yang bersangkutan, belum berfungsinya fungsi pengawasan secara efektif, lemahnya koordinasi antara aparat pengawasan dan aparat penegak hukum, serta lemahnya sistem pengendalian internal.

Kedua, hambatan kultural, yaitu hambatan yang bersumber dari kebiasaan negatif yang berkembang di masyarakat. Termasuk dalam kelompok ini diantaranya meliputi: masih adanya sikap sungkan dan toleran diantara aparatur pemerintah yang dapat menghambat penanganan tindak pidana korupsi, kurang terbukanya pimpinan instansi sehingga sering terkesan toleran dan melindungi pelaku korupsi, campur tangan eksekutif, legislatif dan yudikatif dalam penanganan tindak pidana korupsi, rendahnya komitmen untuk menangani korupsi secara tegas dan tuntas, serta sikap masa bodoh sebagian besar masyarakat terhadap upaya pemberantasan korupsi.

Ketiga, hambatan instrumental, yaitu yang bersumber dari kurangnya instrumen pendukung dalam bentuk peraturan perundangundangan yang membuat penanganan tindak pidana korupsi tidak berjalan sebagaimana mestinya. Keempat, hambatan manajemen, yaitu hambatan yang bersumber dari diabaikannya atau tidak diterapkannya prinsip-prinsip manajemen yang baik yang membuat penanganan tindak pidana korupsi tidak berjalan sebagaimana mestinya.

$\begin{array}{cccc}\text { ISO } & 37001 \text { Sistem Manajemen } & \text { Anti } \\ \text { Penyuapan } & \text { merinci } & \text { persyaratan } & \text { dan }\end{array}$ 
menyediakan panduan untuk menetapkan, menerapkan, memelihara, meninjau dan meningkatkan sistem manajemen anti penyuapan. Sistem tersebut dapat berdiri sendiri atau dapat diintegrasikan dengan keseluruhan sistem manajemen. Standar ini sesuai dengan persyaratan ISO untuk standar sistem manajemen. Persyaratan ini mencakup struktur tingkat tinggi, teks inti yang identik, dan istilah umum dengan definisi inti, dirancang untuk keuntungan dari pengguna yang menerapkan berbagai standar sistem manajemen ISO.

Standar ini dapat digunakan bersamaan dengan standar sistem manajemen lainnya (misal ISO 9001, ISO 14001, ISO/IEC 27001 dan ISO 19600) dan standar manajemen (misal ISO 26000 dan ISO 31000) (ISO 37001 dwi bahasa). Sehingga, standar tersebut cocok dan dapat diterapkan bagi apapun organisasinya terlebih lagi bagi yang sudah menerapkan dasar-dasar sistem manajemen. Penerapan sistem manajemen anti penyuapan dapat membantu suatu organisasi mencegah terjadinya kasus suap yang melibatkan oknum perorangan atau yang terorganisir dilakukan oleh korporasi. Berdasarkan uraian tersebut, tujuan dari penelitian ini adalah untuk menganalisis tingkat kesiapan organisasi dalam implementasi ISO 37001.

\section{TINJAUAN PUSTAKA}

\subsection{Definisi Korupsi dan Suap}

Menurut perspektif hukum, definisi korupsi secara gamblang telah dijelaskan dalam 13 buah Pasal dalam UU No. 31 Tahun 1999 yang telah diubah dengan UU No. 20 Tahun 2001 tentang Pemberantasan Tindak Pidana Korupsi. Berdasarkan pasal-pasal tersebut, korupsi dirumuskan dalam 30 bentuk/jenis tindak pidana korupsi. Pasal-pasal tersebut menerangkan secara terperinci mengenai perbuatan yang bisa dikenakan sanksi pidana karena korupsi. Ketigapuluh bentuk/jenis tindak pidana korupsi tersebut pada dasarnya dapat dikelompokkan sebagai berikut:

1. Kerugian keuangan negara

2. Suap-menyuap

3. Penggelapan dalam jabatan

4. Pemerasan

5. Perbuatan curang

6. Benturan kepentingan dalam pengadaan

7. Gratifikasi

Penyuapan merupakan istilah yang dituangkan dalam undang-undang sebagai suatu hadiah atau janji (giften/beloften) yang diberikan atau diterima meliputi penyuapan aktif dan penyuapan pasif. Ada 3 unsur yang esensial dari delik suap

yaitu:

1. Menerima hadiah atau janji;

2. Berkaitan dengan kekuasaan yang melekat pada jabatan;

3. Bertentangan dengan kewajiban atau tugasnya.

\subsection{Definisi Iklim Organisasi}

Menurut Setiawan (2015), iklim organisasi adalah bagaimana karakteristik yang berasal dari lingkungan berpengaruh terhadap tingkah laku orang yang berada dalam organisasi serta segala sesuatu yang ada dalam organisasi seperti sistem formal, gaya kepemimpinan manajer (informal/formal), faktor lingkungan penting lainnya yang akan berpengaruh terhadap sikap, kepercayaan, nilai dan motivasi orang yang bekerja dalam organisasi tersebut.

Iklim organisasi menurut Wirawan (2008) adalah persepsi anggota organisasi mengenai apa yang ada atau terjadi di lingkungan internal organisasi secara rutin, yang memengaruhi sikap dan perilaku, serta kinerja anggota organisasi. Brown dan Leigh (1996) menyatakan bahwa iklim organisasi adalah keadaan lingkungan organisasi yang dirasakan oleh karyawan yang mengarah pada aspek-aspek seperti: keamanan psikologis dan kebermaknaan psikologis lingkungan kerja. Iklim organisasi di definisikan sebagai atribut persepsi organisasi dan subsistemnya yang tercermin dalam cara organisasi berkaitan dengan karyawannya, kelompok karyawan, dan isu-isu (Gupta, 2008).

\subsection{Kesiapan Perubahan Organisasi}

Menurut Rafferty dkk (2012) kesiapan kelompok kerja dan organisasi terhadap perubahan merupakan kesamaan rasa individu dalam organisasi karena adanya proses interaksi sosial yang menciptakan kesatuan pemikiran sehingga berdampak pada fenomena kolektif di tingkat yang lebih tinggi. Menurut Holt (2007) kesiapan untuk berubah didefinisikan sebagai sikap komprehensif yang secara simultan dipengaruhi oleh isi, proses, konteks dan individu yang terlibat dalam suatu perubahan, merefleksikan sejauh mana kecenderungan individu untuk menyetujui, menerima, dan mengadopsi rencana spesifik yang bertujuan untuk mengubah keadaan saat ini. 
Menurut Weiner (2009) kesiapan organisasi untuk berubah terdiri dari change commitment (komitmen untuk berubah) dan change efficacy (kepercayaan terhadap kemampuan untuk berubah). Change commitment merupakan keyakinan bersama individu dalam organisasi untuk melakukan perubahan karena adanya kesadaran bahwa perubahan yang akan dilakukan akan bermanfaat baik bagi individu secara pribadi maupun bagi organisasi. Sedangkan change efficacy merupakan keyakinan bersama individu dalam organisasi bahwa secara kolektif individu dalam organisasi mampu melakukan perubahan.

\subsection{Manajemen Perubahan}

Menurut Kotter (2011), manajemen perubahan adalah istilah yang seringkali digunakan untuk menjelaskan satu set alat dasar atau struktur agar setiap upaya perubahan dapat dikendalikan. Oleh karena itu manajemen perubahan mengacu pendekatan yang digunakan dalam peralihan individu, tim, dan organisasi untuk mencapai tujuan yang diharapkan pada masa depan. Varkey dan Antonio (2010) berpendapat bahwa manajemen perubahan adalah istilah yang digunakan untuk menjelaskan berbagai tindakan yang dilakukan agar peralihan proses bisnis dari kondisi saat ini pada kondisi yang diharapkan terjadi pada masa depan dapat berjalan lancar baik pada level individu maupun tim. Manajemen perubahan merupakan suatu proses yang sistematis dalam menerapkan pengetahuan, sarana dan sumber daya yang diperlukan untuk memengaruhi perubahan pada orang yang akan terkena dampak dari proses tersebut. Manajemen perubahan juga difahami sebagai upaya yang ditempuh oleh para manajer untuk mengelola perubahan secara efektif, dimana diperlukan pemahaman tentang persoalan motivasi, kepemimpinan, kelompok, konflik, komunikasi dan disiplin (Arifin, 2017).

\subsection{Perbandingan ISO 9001 dan ISO 37001}

Standar ISO 37001 pada dasarnya memiliki struktur yang sama dengan ISO 9001 dimana terdapat 10 klausul. Adapun persamaan dan perbedaan diantara kedua standar terlihat pada Tabel 1 .
Tabel 1. Persamaan dan Perbedaan SNI ISO 9001:2015 dengan SNI ISO 37001:2016

\begin{tabular}{|c|c|c|}
\hline No & SNI ISO 9001:2015 & SNI ISO $37001: 2016$ \\
\hline & \multicolumn{2}{|l|}{ PERSAMAAN } \\
\hline 1 & $\begin{array}{l}\text { Menggunakan } \\
\text { pendekatan siklus } \\
\text { PDCA } \\
\text { (Plan-Do-Check- } \\
\text { Action) }\end{array}$ & $\begin{array}{l}\text { Menggunakan } \\
\text { pendekatan siklus } \\
\text { PDCA ( Plan-Do-Check- } \\
\text { Action) }\end{array}$ \\
\hline 2 & $\begin{array}{l}\text { Memiliki struktur yang } \\
\text { sama sesuai High } \\
\text { Level Standard } \\
\text { 1. Ruang Lingkup } \\
\text { 2. Acuan Normatif } \\
\text { 3. Istilah Definisi } \\
\text { 4. Konteks Organisasi } \\
\text { 5. Kepemimpinan } \\
\text { 6. Perencanaan } \\
\text { 7. Dukungan } \\
\text { 8. Operasi } \\
\text { 9. Evaluasi Kinerja } \\
\text { 10. Peningkatan }\end{array}$ & $\begin{array}{l}\text { Memiliki struktur yang } \\
\text { sama sesuai High Level } \\
\text { Standard } \\
\text { 1. Ruang Lingkup } \\
\text { 2. Acuan Normatif } \\
\text { 3. Istilah Definisi } \\
\text { 4. Konteks Organisasi } \\
\text { 5. Kepemimpinan } \\
\text { 6. Perencanaan } \\
\text { 7. Dukungan } \\
\text { 8. Operasi } \\
\text { 9. Evaluasi Kinerja } \\
\text { 10. Peningkatan }\end{array}$ \\
\hline 3 & $\begin{array}{l}\text { Lingkup Penerapan } \\
\text { Standar } \\
\text { Dapat diterapkan di } \\
\text { semua level organisasi } \\
\text { kecil/besar/privat/public }\end{array}$ & $\begin{array}{l}\text { Lingkup Penerapan } \\
\text { Standar } \\
\text { Dapat diterapkan d } \\
\text { semua level organisas } \\
\text { kecil/besar/privat/public }\end{array}$ \\
\hline 4 & $\begin{array}{l}\text { Berbasis pendekatan } \\
\text { resiko }\end{array}$ & $\begin{array}{l}\text { Berbasis pendekatan } \\
\text { resiko }\end{array}$ \\
\hline 5 & $\begin{array}{lr}\text { Keberhasilan } & \\
\text { penerapan tergantung } \\
\text { komitmen r } & \text { dan } \\
\text { Kepimpinan dari } & \text { top } \\
\text { management } & \text { dan } \\
\text { pelibatan } & \text { seluruh } \\
\text { personil } & \\
\end{array}$ & \begin{tabular}{lr}
\multicolumn{3}{l}{ Keberhasilan } & \\
penerapan & tergantung \\
komitmen & dan \\
Kepimpinan dari & top \\
management & dan \\
pelibatan & seluruh \\
personil &
\end{tabular} \\
\hline 6 & $\begin{array}{lr}\text { Membutuhkan } & \text { sistem/ } \\
\text { informasi } & \text { yang } \\
\text { terdokumentasi } & \text { dalam } \\
\text { penerapannya } & \\
\end{array}$ & $\begin{array}{l}\text { Membutuhkan informasi } \\
\text { yang terdokumentasi } \\
\text { dalam penerapannya }\end{array}$ \\
\hline \multirow[t]{2}{*}{ No. } & SNI ISO 9001:2015 & SNI ISO 37001:2016 \\
\hline & \multicolumn{2}{|l|}{ PERBEDAAN } \\
\hline 1 & $\begin{array}{lr}\text { Penilaian } & \text { resiko } \\
\text { terdapat } & \text { sasaran } \\
\text { mutu } & \text { yang } \\
\text { ditetapkan } & \\
\text { berdasarkan } & \\
\text { kebutuhan } & \text { stake } \\
\text { holder } & \end{array}$ & \begin{tabular}{lr} 
Penilaian & resiko \\
terdapat penyuapan \\
sehingga $\quad$ pada \\
klausul 4 konteks \\
organisasi \\
ditambahkan butir 4.5 \\
\multicolumn{1}{c}{ Penilaian } \\
Resiko Penyuapan
\end{tabular} \\
\hline 2 & $\begin{array}{l}\text { Kebijakan dan } \\
\text { sasaran terkait mutu }\end{array}$ & $\begin{array}{ll}\text { Kebijakan } & \text { dan } \\
\text { sasaran terkait } & \text { anti } \\
\text { penyuapan } & \end{array}$ \\
\hline
\end{tabular}




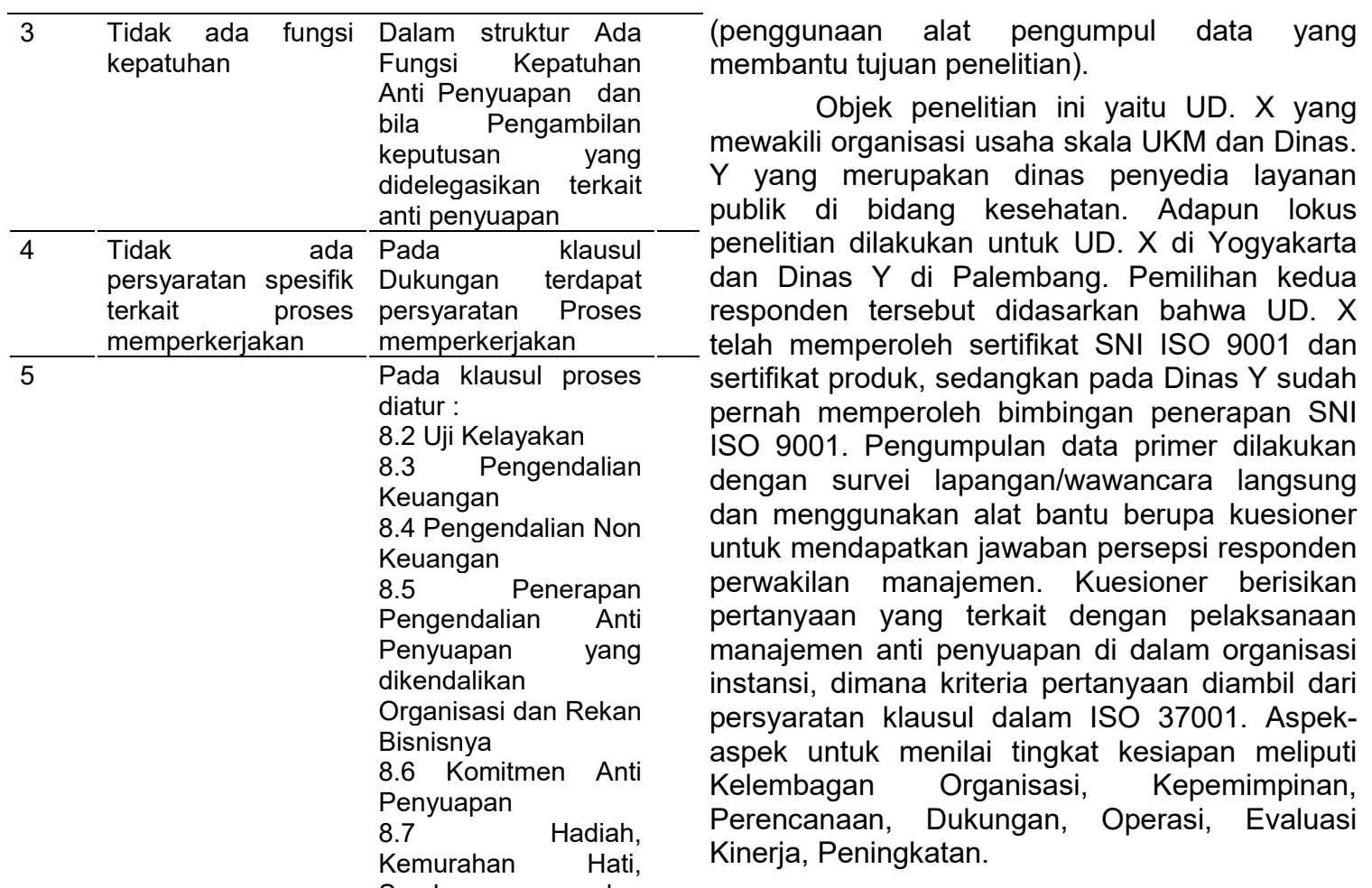

Tabel 2 Level kesiapan penerapan sistem Keuntungan Serupa

8.8 Mengelola Ketidakcukupan

Pengendalian Anti

Penyuapan

8.9 Meningkatkan Kepedulian

8.10 Investigasi dan

Penanganan

Penyuapan

Sumber: Hasil olah data PALS BSN

\section{METODE PENELITIAN}

Penelitian ini merupakan penelitian studi kasus. Metode studi kasus merupakan suatu pendekatan untuk mempelajari, menerangkan, atau menginterpretasikan suatu kasus dalam konteks secara natural atau alamiah tanpa adanya intervensi dari pihak luar (Susanty dkk, 2009). Metode studi kasus dipilih dengan pertimbangan metode tersebut memungkinkan peneliti mengembangkan "grounded theory" yang praktis dan relevan serta memberikan gambaran fenomena yang lebih sesuai dengan kenyataan (Kitazawa \& Sarkiz, 2000). Hanurawan (2012) menjelaskan penelitian studi kasus adalah penelitian yang menggunakan beragam metode dan beragam sumber data. Ini berarti dalam penelitian studi kasus, pendekatan metodologi (alat pengumpul data) yang bersifat eklektik manajemen anti penyuapan.

\begin{tabular}{|c|c|c|}
\hline Level & Nama Level & Karakteristik \\
\hline 1 & Not ready & $\begin{array}{llr}\text { - } & \text { Belum adanya } \\
\text { pemahaman mengenai } & \\
\text { SMAP } & \\
\text { - } & \text { Belum adanya } \\
\text { pemahaman mengenai } & \text { visi, misi dari SMAP } \\
\text { - } & \text { Tidak menggambarkan } \\
& \text { fenomena atau } \\
\text { permasalahan MAP a }\end{array}$ \\
\hline 2 & Preliminary & $\begin{array}{ll}\text { - } & \text { Sudah mengenal } \\
\text { pentingnya kegiatan MAP } \\
\text { - } \\
\text { Proses dalam organisasi } \\
\text { sudah menggambarkan } \\
\text { kegiatan MAP } \\
\text { - Sudah terdapat individu } \\
\text { yang menggalakkan } \\
\text { SMAP } \\
\end{array}$ \\
\hline 3 & Ready & $\begin{array}{l}\text { - Individu dalam organisasi } \\
\text { sudah mempraktikkan } \\
\text { aktivitas yang efektif untuk } \\
\text { mendukung MAP } \\
\text { - Kegiatan MAP sudah } \\
\text { dilaksanakan setiap waktu } \\
\text { di setiap kegiatan } \\
\text { pekerjaan } \\
\text { Kegiatan MAP sudah } \\
\text { dapat ditemukan pada } \\
\text { setiap individu } \\
\text { Sudah ada sistem } \\
\text { dokumentasi }\end{array}$ \\
\hline
\end{tabular}




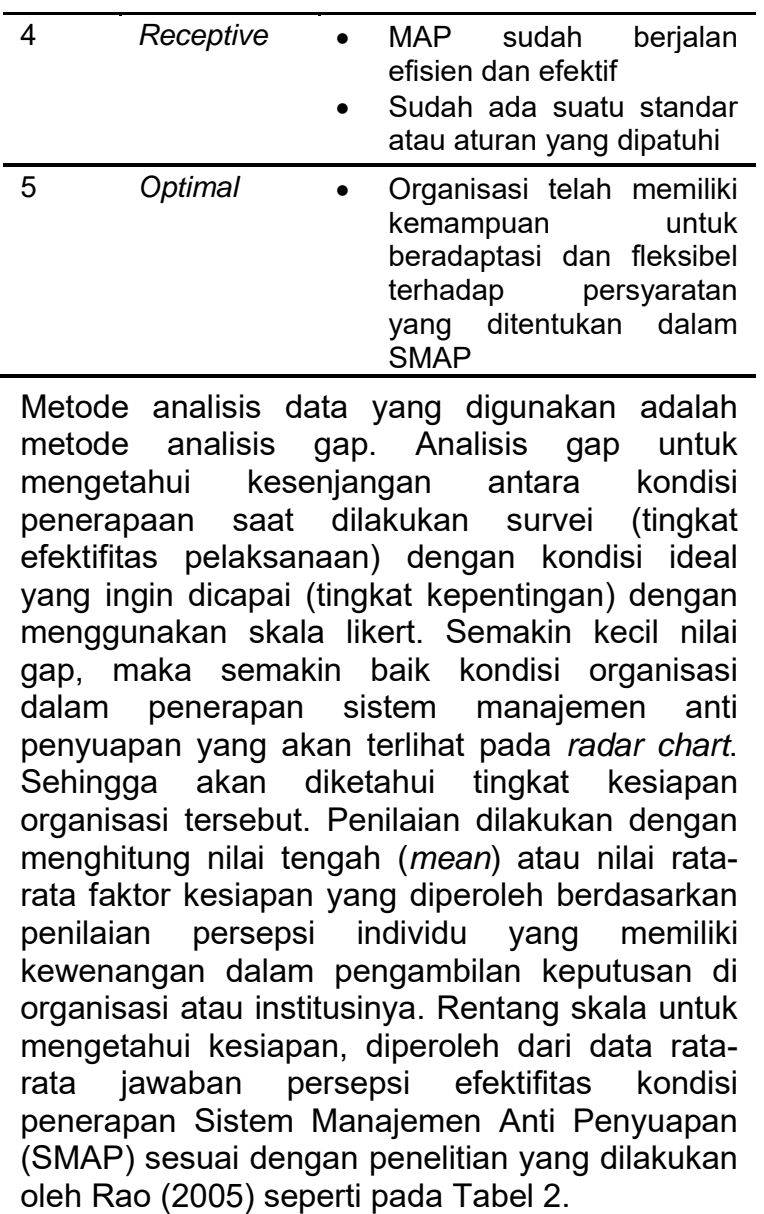

\section{HASIL DAN PEMBAHASAN}

\subsection{Kesiapan Organisasi UD. $X$ dalam Implementasi ISO 37001}

\subsubsection{Aspek Kelembagaan Organisasi}

Dari hasil penilaian tingkat kesiapan pada aspek Kelembagaan Organisasi dimana terdapat 4 jenis pertanyaan, secara keseluruhan kondisi implementasi standar pada organisasinya memiliki nilai rata-rata sebesar 3,5 (berada di rentang level ready). Sedangkan pada tingkat kepentingan memiliki nilai rata-rata 4,10 yang berarti implementasi standar ini dianggap penting. Perbandingan nilainya dapat dilihat pada Gambar 1.

\subsubsection{Aspek Kepemimpinan}

Dari hasil penilaian tingkat kesiapan pada aspek Kepemimpinan dimana terdapat 4 jenis pertanyaan, secara keseluruhan kondisi implementasi standar pada organisasinya memiliki nilai rata-rata sebesar 3,4 (berada di rentang level ready). Sedangkan pada tingkat kepentingan memiliki nilai rata-rata 4,8 yang berarti implementasi standar ini dianggap penting. Perbandingan nilainya dapat dilihat pada Gambar 2.

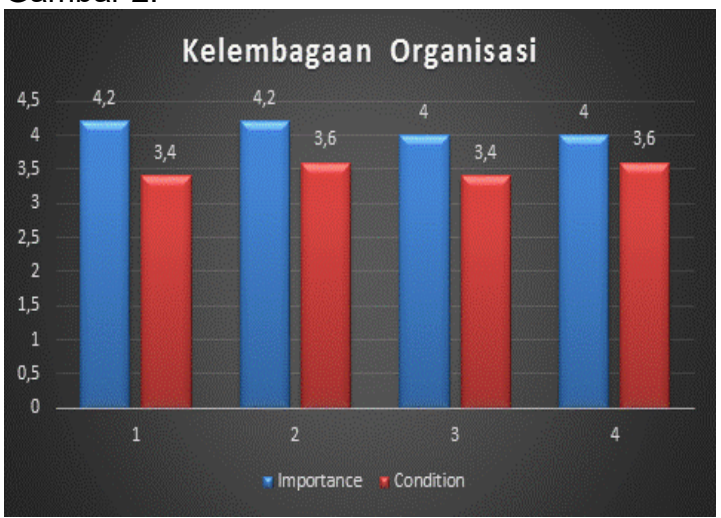

Gambar 1 Analisis kesiapan implementasi standar pada aspek kelembagaan organisasi.

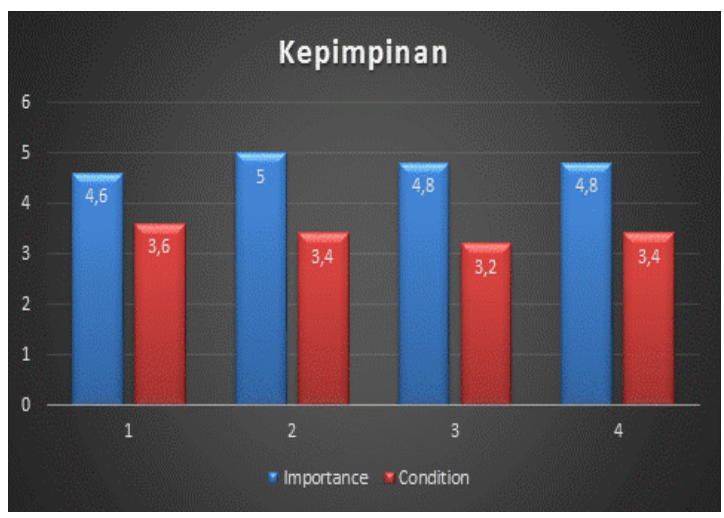

Gambar 2 Analisis kesiapan implementasi standar pada aspek kepemimpinan.

\subsubsection{Aspek Perencanaan}

Dari hasil penilaian tingkat kesiapan pada aspek Perencanaan dimana terdapat 2 jenis pertanyaan, secara keseluruhan kondisi implementasi standar pada organisasinya memiliki nilai rata-rata sebesar 3,3 (berada di rentang level ready). Sedangkan pada tingkat kepentingan memiliki nilai rata-rata 4,2 yang berarti implementasi standar ini dianggap penting. Perbandingan nilainya dapat dilihat pada Gambar 3.

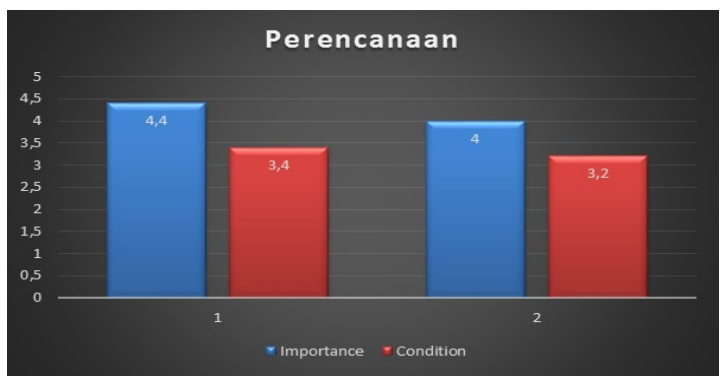

Gambar 3 Analisis kesiapan implementasi standar pada aspek perencanaan. 


\subsubsection{Aspek Dukungan}

Dari hasil penilaian tingkat kesiapan pada aspek Perencanaan dimana terdapat 8 jenis pertanyaan, secara keseluruhan kondisi implementasi standar pada organisasinya memiliki nilai rata-rata sebesar 3,33 (berada di rentang level ready). Sedangkan pada tingkat kepentingan memiliki nilai rata-rata 4,03 yang berarti implementasi standar ini dianggap penting. Perbandingan nilainya dapat dilihat pada Gambar 4.

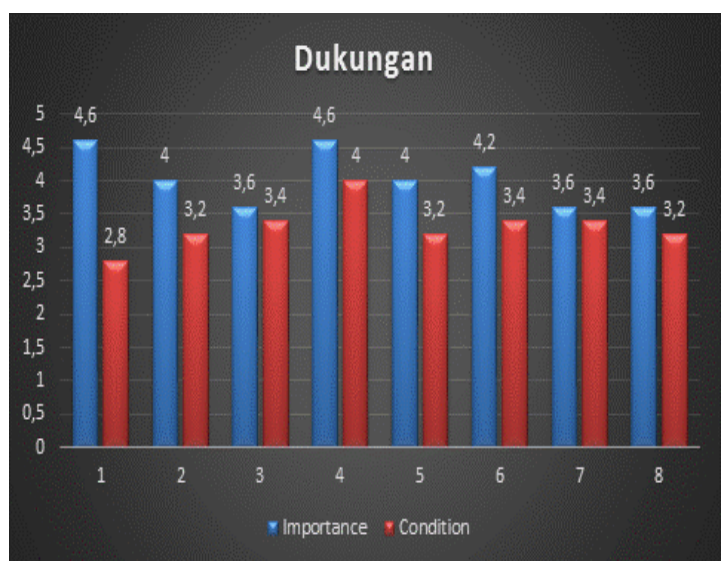

Gambar 4 Analisis kesiapan implementasi standar pada aspek dukungan.

\subsubsection{Aspek Operasi}

Dari hasil penilaian tingkat kesiapan pada aspek Operasi dimana terdapat 10 jenis pertanyaan, secara keseluruhan kondisi implementasi standar pada organisasinya memiliki nilai rata-rata sebesar 3,12 (berada di rentang level ready). Sedangkan pada tingkat kepentingan memiliki nilai rata-rata 3,88 yang berarti implementasi standar ini dianggap cukup penting. Perbandingan nilainya dapat dilihat pada Gambar 5.

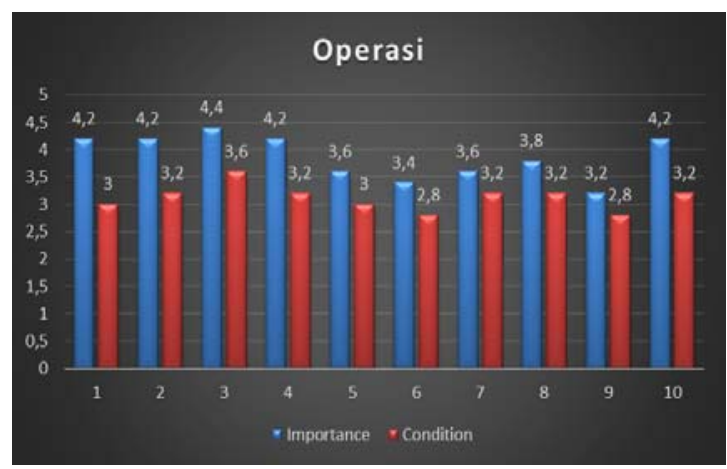

Gambar 5 Analisis kesiapan implementasi standar pada aspek operasi.

\subsubsection{Aspek Tinjauan Manajemen}

Dari hasil penilaian tingkat kesiapan pada aspek Tinjauan Manajemen dimana terdapat 4 jenis pertanyaan, secara keseluruhan kondisi implementasi standar pada organisasinya memiliki nilai rata-rata sebesar 3,20 (berada di rentang level ready). Sedangkan pada tingkat kepentingan memiliki nilai rata-rata 4,10 yang berarti implementasi standar ini dianggap penting. Perbandingan nilainya dapat dilihat pada Gambar 6.

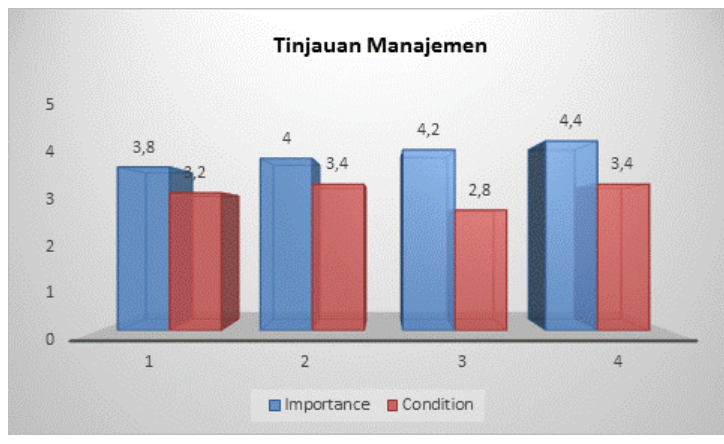

Gambar 6 Analisis kesiapan implementasi standar pada aspek tinjauan manajemen.

\subsubsection{Aspek Peningkatan}

Dari hasil penilaian tingkat kesiapan pada aspek Peningkatan dimana terdapat 2 jenis pertanyaan, secara keseluruhan kondisi implementasi standar pada organisasinya memiliki nilai rata-rata sebesar 3,40 (berada di rentang level ready). Sedangkan pada tingkat kepentingan memiliki nilai rata-rata 4,10 yang berarti implementasi standar ini dianggap penting. Perbandingan nilainya dapat dilihat pada Gambar 7 .

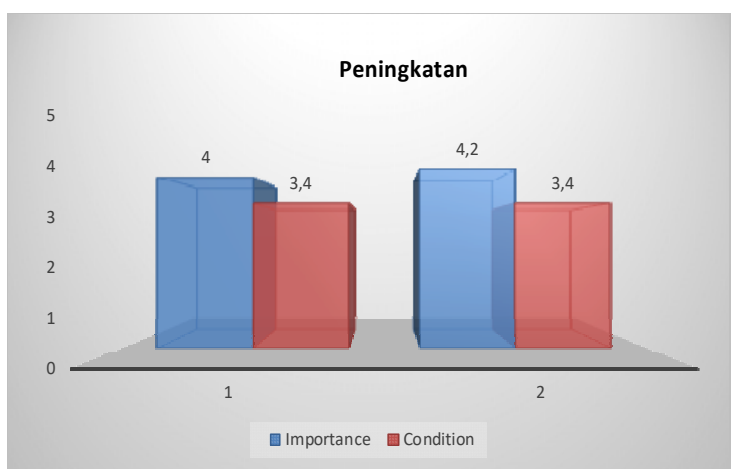

Gambar 7 Analisis kesiapan implementasi standar pada aspek peningkatan.

Berdasarkan nilai dari setiap aspek sesuai standar dalam ISO 37001 diperoleh hasil bahwa semakin kecil gap, maka organisasi semakin siap dalam menerapkan standar. dari tujuh aspek yang dinilai, dapat diketahui bahwa aspek kelembagaan organisasi, aspek dukungan 
dan aspek peningkatan memiliki nilai gap yang rendah secara berturut-turut nilainya $(0,6 ; 0,7$; $0,7)$. Sedangkan aspek-aspek yang masih perlu dilakukan perbaikan/peningkatan antara lain aspek kepemimpinan, perencanaan, operasi dan tinjauan manajemen.

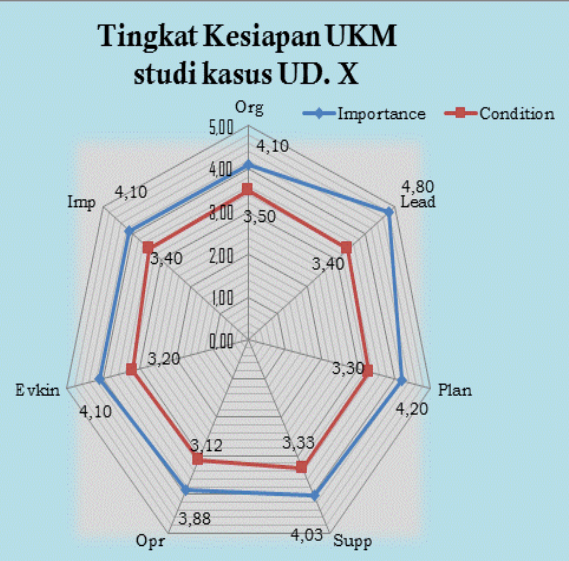

Gambar 8 Analisis radar chart tingkat kesiapan ud. $x$ dalam menerapkan sni iso 37001 .

\subsection{Kesiapan Organisasi Dinas. Y dalam Implementasi ISO 37001}

\subsubsection{Aspek Kelembagaan Organisasi}

Dari hasil penilaian tingkat kesiapan pada aspek Kelembagaan Organisasi dimana terdapat 4 item pertanyaan, secara keseluruhan kondisi implementasi standar pada organisasinya memiliki nilai rata-rata sebesar 2,5 (berada di rentang level preliminary). Sedangkan pada tingkat kepentingan memiliki nilai rata-rata 4,19 yang berarti implementasi standar ini dianggap penting. Perbandingan nilainya dapat dilihat pada Gambar 9.

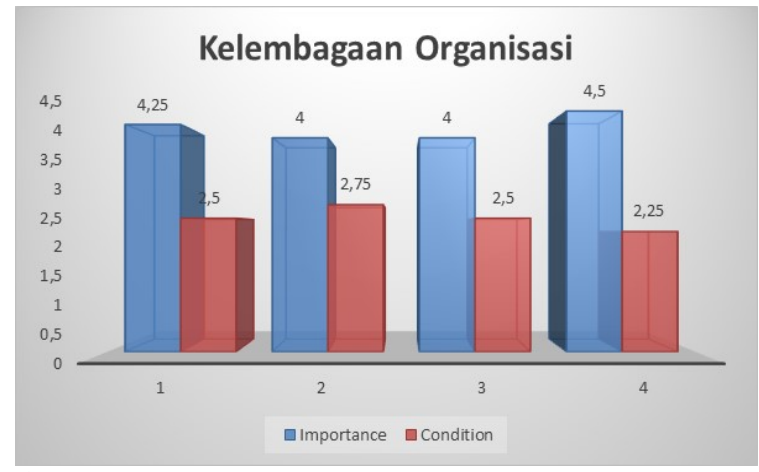

Gambar 9 Analisis kesiapan implementasi standar pada aspek kelembagaan organisasi.

\subsubsection{Aspek Kepemimpinan}

Dari hasil penilaian tingkat kesiapan pada aspek Kepemimpinan dimana terdapat 4 jenis pertanyaan, secara keseluruhan kondisi implementasi standar pada organisasinya memiliki nilai rata-rata sebesar 2,56 (berada di rentang level preliminary). Sedangkan pada tingkat kepentingan memiliki nilai rata-rata 4,63 yang berarti implementasi standar ini dianggap penting. Perbandingan nilainya dapat dilihat pada Gambar 10

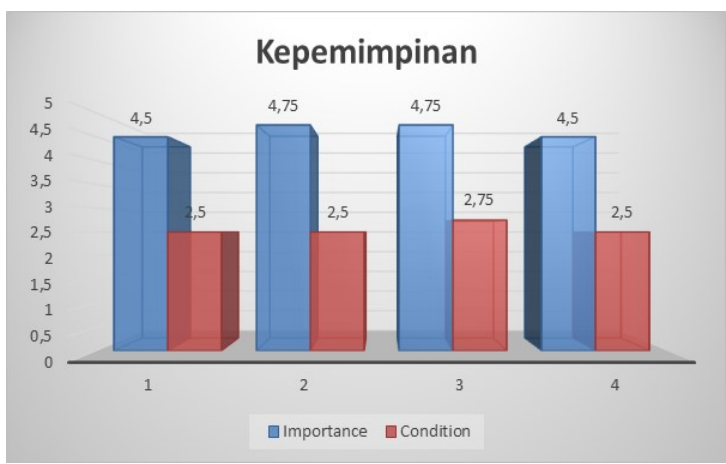

Gambar 10 Analisis kesiapan implementasi standar pada aspek kepemimpinan.

\subsubsection{Aspek Perencanaan}

Dari hasil penilaian tingkat kesiapan pada aspek Perencanaan dimana terdapat 2 jenis pertanyaan, secara keseluruhan kondisi implementasi standar pada organisasinya memiliki nilai rata-rata sebesar 2,38 (berada di rentang level preliminary). Sedangkan pada tingkat kepentingan memiliki nilai rata-rata 4,5 yang berarti implementasi standar ini dianggap penting. Perbandingan nilainya dapat dilihat pada Gambar 11.

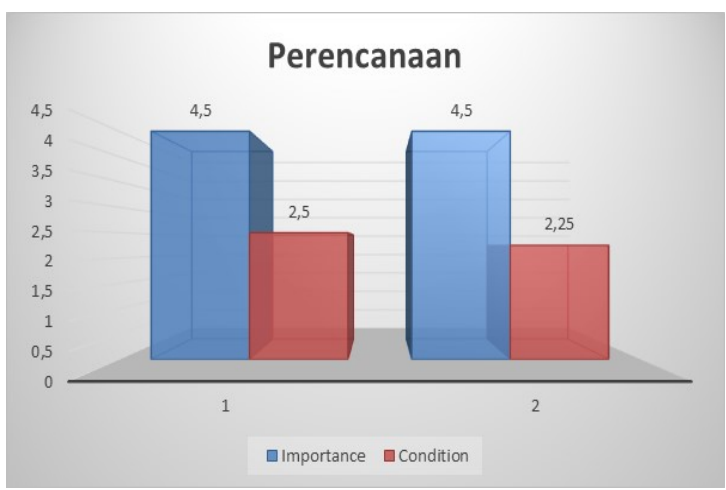

Gambar 11 Analisis kesiapan implementasi standar pada aspek perencanaan.

\subsubsection{Aspek Dukungan}

Dari hasil penilaian tingkat kesiapan pada aspek Perencanaan dimana terdapat 8 jenis pertanyaan, secara keseluruhan kondisi implementasi standar pada organisasinya memiliki nilai rata-rata sebesar 2,56 (berada di 
rentang level preliminary). Sedangkan pada tingkat kepentingan memiliki nilai rata-rata 4,34 yang berarti implementasi standar ini dianggap penting. Perbandingan nilainya dapat dilihat pada Gambar 12.

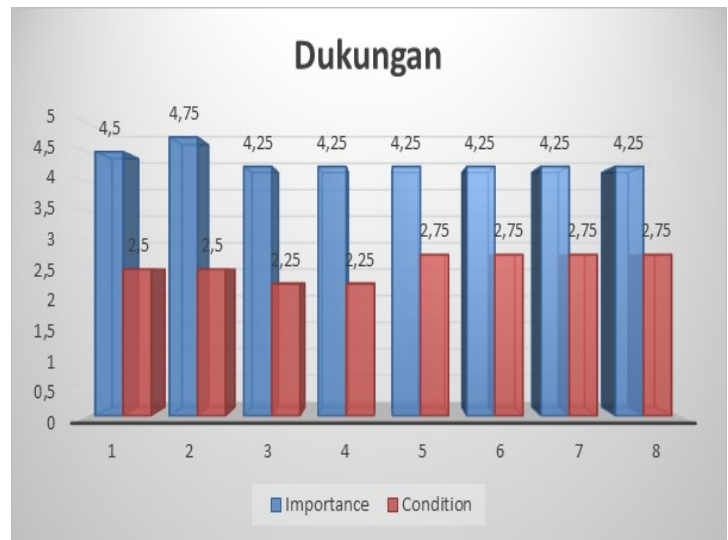

Gambar 12 Analisis kesiapan implementasi standar pada aspek dukungan.

\subsubsection{Aspek Operasi}

Dari hasil penilaian tingkat kesiapan pada aspek Operasi dimana terdapat 10 jenis pertanyaan, secara keseluruhan kondisi implementasi standar pada organisasinya memiliki nilai rata-rata sebesar 2,60 (berada di rentang level preliminary). Sedangkan pada tingkat kepentingan memiliki nilai rata-rata 4,3 yang berarti implementasi standar ini dianggap penting. Perbandingan nilainya dapat dilihat pada Gambar 13.

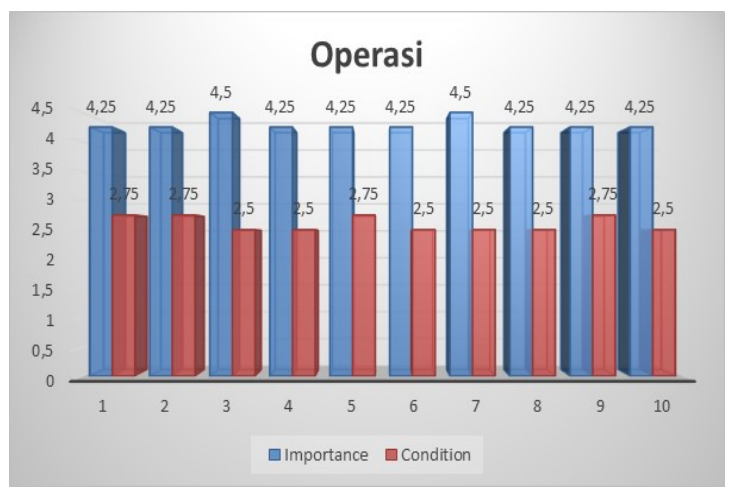

Gambar 13 Analisis kesiapan implementasi standar pada aspek operasi.

\subsubsection{Aspek Tinjauan Manajemen}

Dari hasil penilaian tingkat kesiapan pada aspek Tinjauan Manajemen dimana terdapat 4 jenis pertanyaan, secara keseluruhan kondisi implementasi standar pada organisasinya memiliki nilai rata-rata sebesar 2,5 (berada di rentang level preliminary). Sedangkan pada tingkat kepentingan memiliki nilai rata-rata 4,25 yang berarti implementasi standar ini dianggap penting. Perbandingan nilainya dapat dilihat pada Gambar 14.

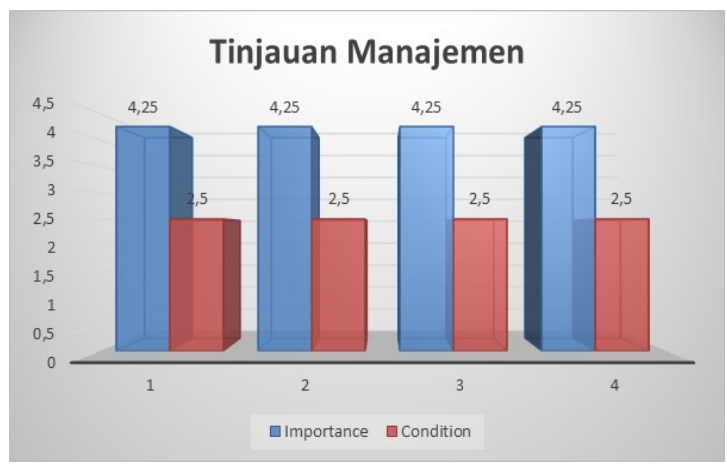

Gambar 14 Analisis kesiapan implementasi standar pada aspek tinjauan manajemen.

\subsubsection{Aspek Peningkatan}

Dari hasil penilaian tingkat kesiapan pada aspek Peningkatan dimana terdapat 2 jenis pertanyaan, secara keseluruhan kondisi implementasi standar pada organisasinya memiliki nilai rata-rata sebesar 2,75 (berada di rentang level preliminary). Sedangkan pada tingkat kepentingan memiliki nilai rata-rata 4,25 yang berarti implementasi standar ini dianggap penting. Perbandingan nilainya dapat dilihat pada Gambar 15.

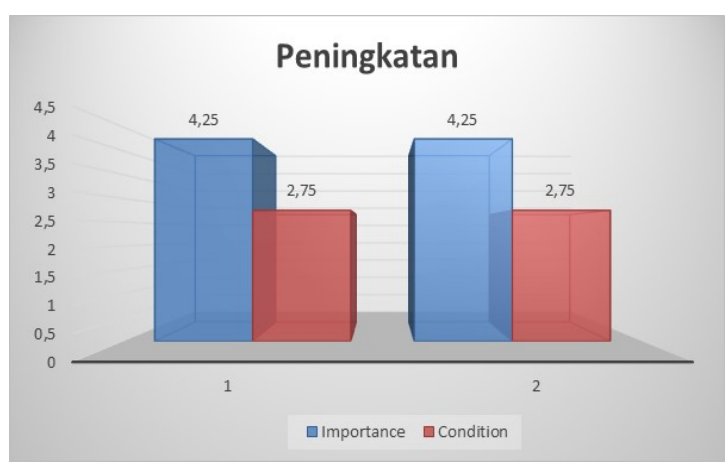

Gambar 15 Analisis Kesiapan Implementasi Standar pada Aspek Peningkatan.

Berdasarkan nilai dari setiap aspek sesuai standar dalam SNI ISO 37001 diperoleh hasil bahwa semakin kecil gap, maka organisasi semakin siap dalam menerapkan standar. dari tujuh aspek yang dinilai, dapat diketahui bahwa seluruh aspek masih dalam level preliminary atau belum ada aspek yang dinilai siap. Oleh karena itu, Dinas $Y$ sebagai unit layanan publik harus meningkatkan perbaikan-perbaikan di seluruh 
aspek untuk mendukung penerapan sistem manajemen anti penyuapan di dalam organisasinya.

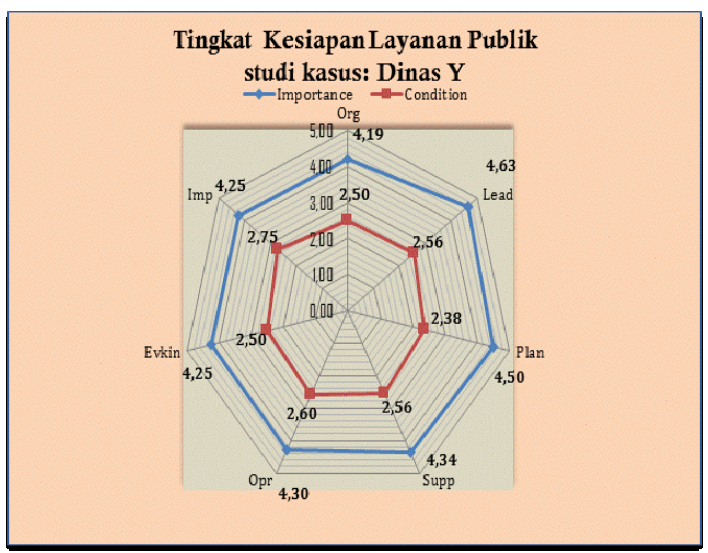

Gambar 16 Analisis radar chart tingkat kesiapan dinas y dalam menerapkan SNI ISO 37001.

\section{KESIMPULAN}

Berdasarkan hasil penilaian yang menggunakan radar chart pada organisasi UD. $X$ dapat disimpulkan bahwa tingkat efektifitas pelaksanaan (kondisi saat penilaian) pada tujuh aspek kriteria sesuai standar mempunyai nilai rata-rata 3,32 atau berada pada level ready/siap, sedangkan tingkat kepentingan diimplementasikannya standar menurut persepsi para responden mempunyai nilai rata-rata 4,17 atau dianggap penting. Nilai gap-nya sebesar 0,85 (sangat kecil). Organisasi UD.X sudah mampu memahami dan menerapkan sistem manajemen anti penyuapan dalam kegiatan bisnisnya meskipun pada tahap awal, upayaupaya peningkatan perbaikan tetap dilakukan agar secara sistem dapat berjalan optimal.

Sementara itu, hasil penilaian yang menggunakan radar chart pada organisasi Dinas $Y$ dapat disimpulkan bahwa tingkat efektifitas pelaksanaan (kondisi saat penilaian) pada tujuh aspek kriteria sesuai standar mempunyai nilai rata-rata 2,55 atau berada pada level preliminary, sedangkan tingkat kepentingan diimplementasikannya standar menurut persepsi para responden mempunyai nilai rata-rata 4,35 atau dianggap penting. Nilai gap-nya sebesar 1,8 (kecil). Upaya-upaya perbaikan dan peningkatan pemahaman secara menyeluruh dalam organisasi meliputi tujuh aspek sesuai standar SNI ISO 37001 perlu segera dilakukan mengingat core business dari organisasi ini memberikan layanan kepada publik di bidang kesehatan.

\section{UCAPAN TERIMA KASIH}

Ucapan terima kasih kami sampaikan kepada Pusat Penelitian dan Pengembangan Standardisasi BSN yang telah membiayai penelitian ini pada Tahun 2017. Ucapan terima kasih juga kami sampaikan kepada pihak-pihak yang mendukung penelitian ini

\section{DAFTAR PUSTAKA}

Arifin, M. (2017). Strategi Manajemen Perubahan dalam Meningkatkan Disiplin di Perguruan Tinggi. Jurnal EduTech. Vol.3, No.1, 117-132.

Brown, P. S., \& Leigh, W.T. (1996). A new look at psychological climate and its relationship to job involvement, effort and performance. Journal of Applied Psychology, 81(4), 358-368.

Djoyosoekarto, Agung, Diani Sadiawati, Hera Setiawati. (2008). Membangun Sistem Integritas dalam Pemberantasan Korupsi di Daerah, Kemitraan. Jakarta

Fauzan M, dkk. (2012). Implementasi Pemerintahan yang Bersih dalam Kerangka Rencana Aksi Daerah Pemberantasan Korupsi (RAD-PK) Studi di Kabupaten Pemalang. Jurnal Dinamika Hukum. Vol.12, No.3, 448-463.

Gupta, A. (2008). Organizational Climate Study. Institute of Rural Management, Anand, India. Organizational Traineeship Segment (PRM 28055).

Hanurawan, F. (2012). Metode Penelitian Kualitatif dalam IImu Psikologi. Surabaya: Komisi Peningkatan Kinerja Masyarakat (KPKM) Universitas Airlangga.

Holt, Daniel., Armenakis, Field, S., \& Harris, G.(2007). Readiness for organizational change thesystematic development of ascale. The journal of applied behavioral science, Vol. 43 No. 2, 232-255.

ISO 9000:2015. (2015). Quality management systems - Fundamentals and vocabulary, telah diadopsi secara identik menjadi SNI ISO 9000:2015, Sistem manajemen mutu - Dasar-dasar dan kosakata.

ISO 9001:2015. (2015). Quality management systems - Requirements, telah diadopsi secara identik menjadi SNI ISO 9001:2015, Sistem manajemen mutu Persyaratan. 
Kitazawa, Shinichi dan Sarkiz (2000). The Relationship Between ISO 14001 and Continuous Source Reduction Program. International Journal of Operations \& Production Management, Vol. 20 No. 2, Hal. 225-248.

Kotter, J. (2011). Change Management vs. Change Leadership-What's The Difference?. Retrieved April, 23, 2018 from.http://www.forbes.com/sites/johnkott er/2011/0 7/12/change-management-vschange- leadership-whats-thedifference/.

Komisi Pemberantasan Korupsi. (2016). Rekapitulasi Tindak Pidana Korupsi. Retrieved June, 29, 2018 from https://acch.kpk.go.id/id/statistik/tindakpidana-korupsi.

Rafferty, A. E., Jimmieson, N. L., et al. (2012). Change Readiness: A Multilevel Review. Journal of Management 2013, 39: 110135. Retrieved April, 24, 2018 from http://jom.sagepub.com/content/39/1/110

Rao, M. 2005. "Knowledge Management Tools and Techniques". Elsevier ButterworthHeinemann. Oxford. UK.

Setiawan, K C. (2015). Pengaruh Iklim Organisasi Terhadap Kinerja Karyawan Level Pelaksana di Divisi Operasi
PT.Pusri Palembang. Jurnal Psikologi Islami. Vol.1, No.1, 23-32.

Subinarto, Djoko. (2017). "Suap \& Pramatisme Korporasi”, http://www.pikiranrakyat.com/opini/2017/ 01/12/ suap-pragmatisme-korporasi390414, diakses tanggal 25 April 2018.

Suprapto \& Lukiawan, R. (2017). Kelembagaan Sistem Akreditasi dan Sertifikasi SNI ISO 37001 Terkait Sistem Manajemen Anti Penyuapan. Jurnal Standardisasi. Vol. 19, No.2, hal. 145-154.

Susanty, Aries dkk (2009). Hubungan Standar Produk dengan Inovasi Produk pada Industri Elektronik (Studi Kasus Pada PT. Hartono Istana Teknologi), Jurnal Standarisasi.

Varkey, P. dan Kayla Antonio. (2010). Change Management for Effective Quality Improvement: A Primer. American Journal of Medical Quality, XX(X): 1-6. Retrieved April, 25, 2018 from http://ajm.sagepub.com/content/early/201 0/04/30/1062860610361625.

Weiner, Bryan J. (2009). A Theory of Organization Readiness for Change.

Wirawan. (2008). Budaya dan iklim organisasi. Jakarta: Salemba Empat. 